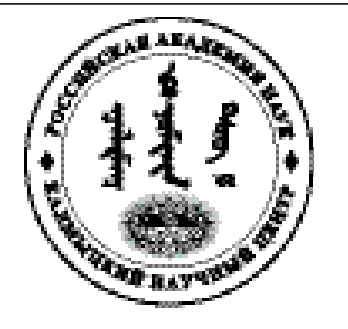

Published in the Russian Federation

Oriental Studies (Previous Name: Bulletin of the Kalmyk Institute

for Humanities of the Russian Academy of Sciences)

Has been issued as a journal since 2008

ISSN: 2619-0990; E-ISSN: 2619-1008

Vol. 13, Is. 5, pp. 1415-1437, 2020

DOI: $10.22162 / 2619-0990-2020-51-5-1415-1437$

Journal homepage: https://kigiran.elpub.ru

УДК 81-23

DOI: $10.22162 / 2619-0990-2020-51-5-1415-1437$

\title{
Еще раз о формах показателя множественного числа в тюркских языках
}

Анна Владимировна Дьбо, Лидия Фатиховна Абубакирова ${ }^{2}$, Марк Михайлович

Зимин ${ }^{3}$ Евгения Владимировна Коровина 4 , Зарема Калабзаровна Кочакаева Александр Владимирович Шаров

${ }^{1}$ Институт языкознания РАН (д. 1, стр. 1, Большой Кисловский пер., 125009 Москва, Российская Федерация); Высшая школа экономики (д. 20, ул. Мясницкая, 101000 Москва, Российская Федерация); Томский государственный университет (д. 33, просп. Ленина, 634050 Томск, Российская Федерация)

член-корреспондент РАН, доктор филологических наук, профессор, заведующий отделом

iD 0000-0002-6077-7183. E-mail: adybo@iling-ran.ru

2 Томский государственный университет (д. 33, просп. Ленина, 634050 Томск, Российская Федерация)

кандидат филологических наук, доцент, старший научный сотрудник

iD 0000-0002-1530-5590. E-mail: lidiya_bspu@mail.ru

${ }^{3}$ Институт языкознания РАН (д. 1, стр. 1, Большой Кисловский пер., 125009 Москва, Российская Федерация)

лаборант-исследователь

iD 0000-0002-2043-9868. E-mail: ung.ofelia@gmail.com

${ }^{4}$ Институт языкознания РАН (д. 1, стр. 1, Большой Кисловский пер., 125009 Москва, Российская Федерация)

младший научный сотрудник

iD 0000-0002-3072-585X. E-mail: evkorovina@iling-ran.ru

${ }^{5}$ Институт языкознания РАН (д. 1, стр. 1, Большой Кисловский пер., 125009 Москва, Российская Федерация)

кандидат филологических наук, младший научный сотрудник

iD 0000-0001-8759-1592. E-mail: z.tarkovskaya@gmail.com

${ }^{6}$ Институт языкознания РАН (д. 1, стр. 1, Большой Кисловский пер., 125009 Москва, Российская Федерация)

лаборант-исследователь

iD 0000-0001-9803-9330. E-mail: ghauasha@gmail.com 
(C) КалмНЦ РАН, 2020

(ㄱ Дыбо А. В., Абубакирова Л. Ф., Зимин М. М., Коровина Е. В., Кочакаева З. К., Шаров А. В., 2020

Аннотация. В статье продолжается обсуждение типов изоглосс и их релевантности для пратюркской реконструкции и реконструкции промежуточных узлов тюркского генеалогического древа. Цель исследования - проверить возможность и надежность реконструкции морфонологического облика некоторых аффиксов для промежуточных языков-предков стандартно-тюркской группы (огузских, «кыргызских», алтайских, карлукских, тобасских, кыпчакских). Здесь мы привлекаем к рассмотрению не только аффикс множественного числа *-lar, но и вообще словоизменительные и словообразовательные аффиксы, начинающиеся на *-1. Используются методы ступенчатой реконструкции одновременно с морфонологическими методами выделения классов позиций и распределения по ним классов алломорфов аффиксов. В качестве материала использованы полевые записи диалектов, диалектологические публикации, как современные, так и XIX в., а также материал письменных памятников. Результатыл. Данные, как новейшие полевые, так и сведения из классических источников, при правильном применении методов ступенчатой реконструкции показывают, что для большинства рассматриваемых стандартно-тюркских клад не реконструируется алломорфия аффиксов на *-1. Ни для праогузского, ни для пракарлукского, ни для пракыпчакского не удаётся доказать существование ассимиляции *-1-аффикса конечному согласному основы. Также оказывается, что существующие в современных языках правила алломорфии вторичны. Одинаковые чередования *-1-аффикса развились в целом ряде идиомов (диалектный башкирский, диалектный казахский, «кыргызские», тобасские, якутско-долганский) в результате контактных процессов, которые существенно моложе, чем те историко-фонетические процессы, которые сформировали эти группы идиомов.

Ключевые слова: тюркские языки, диалектология, кыпчакские языки, огузские языки, морфонология, памятники письменности, фонетическая реконструкция, морфонологическая реконструкция

Благодарность. Работа выполнена по проекту РНФ № 18-18-00501 «Создание электронного диалектологического атласа тюркских языков России». Авторы выражают благодарность также всем информантам, активистам и коллегам, помогавшим при сборе диалектологического материала.

Для цитирования: Дыбо А. В., Абубакирова Л. Ф., Зимин М. М., Коровина Е. В., Кочакаева З. К., Шаров А. В. Еще раз о формах показателя множественного числа в тюркских языках // Oriental Studies. 2020. T. 13. № 5. C. 1415-1437. DOI: 10.22162/2619-0990-2020-51-5-1415-1437

UDC $81-23$

DOI: $10.22162 / 2619-0990-2020-51-5-1415-1437$

\title{
Once Again about Allomorphism of the Plural -lar in Turkic Languages
}

\author{
Anna V. Dybo', Lidia F. Abubakirova², Mark M. Zimin ${ }^{3}$ Evgeniya V. Korovina ${ }^{4}$, \\ Zarema K. Kochakaeva ${ }^{5}$, Aleksandr V. Sharov ${ }^{6}$ \\ ${ }^{1}$ Institute of Linguistics of the RAS (1/1, Bolshoi Kislovsky Lane, Moscow 125009, Russian \\ Federation); Higher School of Economics (20, Myasnitskaya St., Moscow 101000, Russian \\ Federation); Tomsk State University (33, Lenin Ave., Tomsk 634050, Russian Federation) \\ Corresponding Member of the RAS, Dr. Sc. (Philology), Professor, Head of Ural-Altaic Department \\ (iD) 0000-0002-6077-7183. E-mail: adybo@iling-ran.ru
}


${ }^{2}$ Tomsk State University (33, Lenin Ave., Tomsk 634050, Russian Federation)

Cand. Sc. (Philology), Associate Professor, Senior Research Associate

iD 0000-0002-1530-5590. E-mail: lidiya_bspu@mail.ru

${ }^{3}$ Institute of Linguistics of the RAS (1/1, Bolshoi Kislovsky Lane, Moscow 125009, Russian

Federation)

Research Laboratory Assistant

(iD) 0000-0002-2043-9868. E-mail: ung.ofelia@gmail.com

${ }^{4}$ Institute of Linguistics of the RAS (1/1, Bolshoi Kislovsky Lane, Moscow 125009, Russian

Federation)

Junior Research Associate

iD 0000-0002-3072-585X. E-mail: evkorovina@iling-ran.ru

${ }^{5}$ Institute of Linguistics of the RAS (1/1, Bolshoi Kislovsky Lane, Moscow 125009, Russian

Federation)

Cand. Sc. (Philology), Junior Research Associate

(iD) 0000-0001-8759-1592.E-mail: z.tarkovskaya@gmail.com

${ }^{6}$ Institute of Linguistics of the RAS (1/1, Bolshoi Kislovsky Lane, Moscow 125009, Russian

Federation)

Research Laboratory Assistant

iD 0000-0001-9803-9330. E-mail: ghauasha@gmail.com

(c) KalmSC RAS, 2020

(c) Dybo A. V., Abubakirova L. F., Zimin M. M., Korovina E. V., Kochakaeva Z. K., Sharov A. V., 2020

Abstract. Introduction. The article continues the discussion of isogloss types and their relevance for the Proto-Turkic reconstruction and reconstruction of the intermediate nodes of the Turkic family tree. Goals. The paper makes another attempt to reconstruct the morphophonological appearance of some affixes for intermediate languages-ancestors of the standard Turkic group (Oguz, 'Kyrgyz', Altai, Karluk, Toba, Kypchak). The study draws into consideration not only the plural affix *-lar, but in general inflectional and derivational affixes starting with *-l. Materials and Methods. Methods of stepwise reconstruction are used simultaneously with morphophonological methods of identifying classes of positions and distribution of classes of allomorphs. Field records of dialects, dialectological publications, both modern ones and those of the $19^{\text {th }}$ century, as well as written monuments were used as research material. Results. Both modern field data and classical sources, with the correct application of the methods of stepwise reconstruction, point that affixal *-l has no alternants in proto-Oghuz, protoKarluk and proto-Qypchaq. All instances of alternation in modern idioms like dialectal Bashkir, dialectal Kazakh, 'Qyrghyz' languages, Yakut-Dolghan and Toba languages are to be classified as recent areal innovation. This is deduced due to the nature of morphophonological rules in these languages - neither is applyable for the proto-Common-Turkic stem auslaut, but instead is limited to forms that are specific to each separate group in question.

Keywords: Turkic languages, dialectology, Kipchak languages, Oghuz languages, morphophonology, written monuments, areal linguistics, dialectal continuum, historical phonetics, morphonological reconstruction

Acknowledgements. The reported study funded by Russian Science Foundation, project no. 18-1800501 'Digital Dialectological Atlas of Russia's Turkic Languages'. The authors are also grateful to all informants and colleagues who assisted in collecting dialectological materials.

For citation: Dybo A. V., Abubakirova L. F., Zimin M. M., Korovina E. V., Kochakaeva Z. K., Sharov A. V. Once Again about Allomorphism of the Plural -lar in Turkic Languages. Oriental Studies. 2020. Vol. 13(5): 1415-1437. (In Russ.). DOI: 10.22162/2619-0990-2020-51-5-1415-1437 


\section{Введение}

Настоящая статья продолжает обсуждение типов изоглосс в тюркских диалектах, начатое на страницах журнала работами [Норманская, Гаджиева 2020] и [Дыбо и др. 2020] (и ранее [Дыбо 2017]). Нельзя не одобрить замысел Ю. В. Норманской и А. А. Гаджиевой провести ступенчатую реконструкцию показателя множественного числа *-LAr и попытаться спроецировать на локальные прауровни его морфонологическое поведение. Применяемые ими методы анализа, в том числе ареалогические, весьма актуальны для тюркского языкознания и выдержаны с теоретико-лингвистической точки зрения. Использован ранее мало рассматривавшийся материал миссионерских кириллических памятников тюркских языков, который в ряде случаев позволяет получить информацию о хронологически предшествующих современному состояниях языков и тем помочь в реконструкции. В настоящей работе нам хотелось бы, разобрав некоторые моменты, дать дополненную и уточненную интерпретацию ситуации с показателями множественного числа в тюркских языках, относящихся классификационно к группе обще- или стандартно-тюркских (то есть, не касаясь булгарской группы). В результате этих уточнений выводы по групповым реконструкциям морфонологического поведения аффиксов множественного числа несколько изменяются. Наши результаты получены при работе над составлением базы данных Атласа диалектов тюркских языков России; использованы как материалы Атласа, так и релевантные опубликованные материалы.

1. Исходные положения. Прежде всего отметим, что инновационный характер морфонологических вариантов аффикса множественного числа *-1Ar в позициях консонантных сандхи не вызывает сомнения у «мэйнстримных» тюркологов, поскольку эти варианты позиционные и распределены обычно точно так же, как алломорфы множества других морфем с исходным *1(например, аффикс отыменного глаголообразования *1А-, аффикс-атрибутивизатор
*lXG, аффикс абстрактного имени * $(\mathrm{XK})^{1}$. Кроме того, во многих тюркских языках все эти аффиксы не имеют консонантных чередований и при этом демонстрируют всегда -1-; для них решение о первичности этого варианта значительно логичнее, чем предположение о вторичной унификации -1-ступени при ранее имевшемся чередовании, поскольку сложно было бы объяснить, почему в этих языках обобщились именно варианты с -1-. Предположение ряда казахских ученых о первичности формы аффикса на -t- никогда не находило себе сторонников среди историков языка, еще и потому, что в древних памятниках существует только вариант $-1 \mathrm{Ar}^{2}$, и потому, что вариант после гласной, ожидаемо наименее подверженный влиянию консонантных ассимиляций, почти во всех описанных идиомах выступает как -lAr.

2. Методологические предпосылки. Принципиальный вопрос при ступенчатой реконструкции алломорфии аффиксов для каждого восстанавливаемого этапа решить, не произошло ли с данным аффиксом изменений на морфонологическом уровне (не поменялся ли в процессе истории его морфонемный состав). Такую ситуацию мы наблюдаем в башкирском языке, например, для аффикса претерита $-\mathrm{NI}^{4}$, который попал в один класс чередований с аффиксами Асс $-\mathrm{NI}^{4}$, Gen $-\mathrm{NI}^{4} \mathrm{y}$, при том, что данные других современных языков и письменных памятников предполагают форму $\mathrm{DI}^{4}$ (т. е. попадание в один класс с аффиксом локативного падежа -*DA и аффиксом каузатива *-DIr-, см.: [Дыбо 2012: 68]). Для аффикса множественного числа этот вопрос, по-видимому, можно решить, выясняя на каждом этапе, попадает ли он в тот же класс чередований, что *la-, *IIG, *1IK. (Для литературно-

\footnotetext{
${ }^{1}$ Исключением является поведение аффикса множественного числа *-1Ar в башкирском литературном языке, отличающееся от поведения других аффиксов на *1-. Причина здесь экстралингвистическая, восходящая к истории создания нормы современного башкирского литературного языка (см.: [Дыбо 2012: 68; Грамматика 1981: 11]).

${ }^{2}$ См., например: [Erdal 2004: 158-160]
} 
го башкирского ответ отрицательный, см.: [Дыбо 2012: 69]). Этот вопрос, к сожалению, не затрагивается в статье [Норманская, Гаджиева 2020]. Мы попробуем ниже отметить его: смена морфонологического класса аффиксами является одним из предметов картографирования в нашем атласе.

3. Материалы исследования. Следует заметить, что, хотя, безусловно, изучение миссионерских кириллических памятников XIX - начала XX в. может дать существенные результаты для поздней истории кыпчакских языков, неправомерно называть их «первыми книгами на кыпчакских языках». Для кыпчакских языков имеются существенно более ранние памятники, чем миссионерские кириллические памятники. Это, во-первых, тексты в арабице, которая вполне способна была бы различать $1, \mathrm{t}$ и $\mathrm{d}$ в формах как множественного числа, так и у других аффиксов на -*1-. Пометы «в языке кыпчаков» и под. появляются уже в словаре Махмуда Кашгарского [Clauson 1972: XIX], т. е. в памятнике XI в.; правда, им не всегда можно доверять. Достоверно кыпчакские памятники известны с XIII в. Конечно, язык этих текстов подвержен влиянию средневековых литературных языков, однако мы находим в них некоторые отступления, указывающие на особенности диалектов авторов и переписчиков. Во-вторых, это латинографические миссионерские и просто описательные тексты XIV-XVIII вв. См. перечисление и краткие характеристики этих памятников, например, в [Гаркавец 2019: 5-80]. Для решения вопроса о реконструкции алломорфии аффикса множественного числа для различных узлов генеалогического древа полезно проверить, когда вообще зафиксированы варианты аффикса, а также, как в соответствующих источниках ведут себя по крайней мере еще три «диагностических» аффикса *la-, *IIG, *IIK.

Рассмотрим, как ведут себя все эти аффиксы в средневековых и несколько более поздних памятниках письменности, и в наследующих им современных идиомах.

А. Рунические, древне-уйгурские, караханидские письменные памятники: чередований нет - см. [Erdal 2004: 114, 159; Erdal 1991: 139, 429-455; и др.].
Б. Огузские памятники. Здесь мы опираемся прежде всего на материал в [Adamović 1985]. Уверенно огузские памятники появляются с XIII в. По имеющимся исследованиям, форм с консонантными ассимиляциями в интересующих нас аффиксах не обнаруживается в арабографических памятниках вплоть до XX в. Но и латинографические описательные грамматики и транскрипционные памятники староосманского языка, появляющиеся с XVI в., также не показывают ассимиляций вплоть до конца XVIII в., когда под 1790 годом находим guieursunner „Nutzen haben“ и под. [Adamović 1985: 240]. Вероятно, можно довольно уверенно утверждать, что в реальной речи такие формы не появлялись раньше XVIII в., поскольку вообще говоря, в османских памятниках обнаруживается довольно много различных диалектных особенностей [Adamović 1985: 321-331], в том числе написания с ассимиляциями ossum, osun вместо olsun 'да будет' и под. появляются в латинографических описаниях с XVI в., поэтому трудно было бы считать, что ассимилированные формы не выписывались из-за строгого следования правилам литературного языка.

Современные огузские диалекты (см. источники материала в [СИГТЯ 2002]) демонстрируют следующее географическое распределение этого явления:

На карте огузских идиомов изоглосса ассимиляции $1>\mathrm{n}$ при основах на носовой довольно беспорядочно располагается на фоне сохранения 1 в этой позиции; обобщение этих данных с данными по памятникам с очевидностью указывает на то, что для праогузского состояния не может восстанавливаться вариант окончания $\mathrm{pl}-\mathrm{nAr}$ после основ на носовой. Кроме того, оказывается, что в центре зоны огузских диалектов, совершенно не связанном с восточной зоной кыпчакских языков, возникают инновационные t- и d-варианты L-аффиксов после основ на шумные (поскольку это не только аффиксы множественного числа, невозможно связать эти варианты с реликтом древнетюркского множественного числа на t); обращает на себя внимание также халаджское явление d-вариантов L-аффиксов у основ на $\mathrm{n}$ (при n-вариантах этих же аффиксов у основ на $\mathrm{m}$ ), что также говорит о независимой инновации. 
Oriental Studies. 2020. Vol. 13. Iss. 5

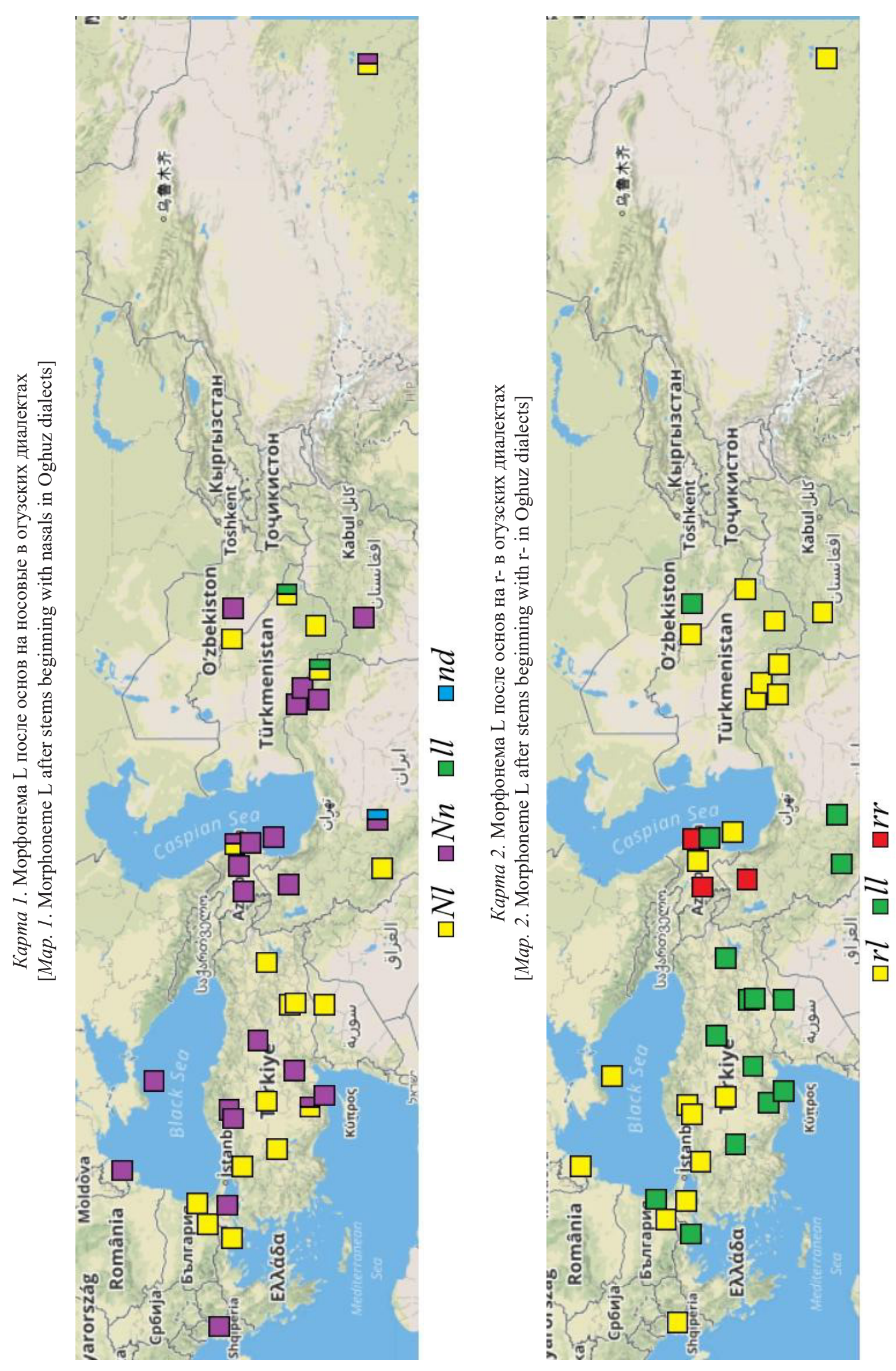



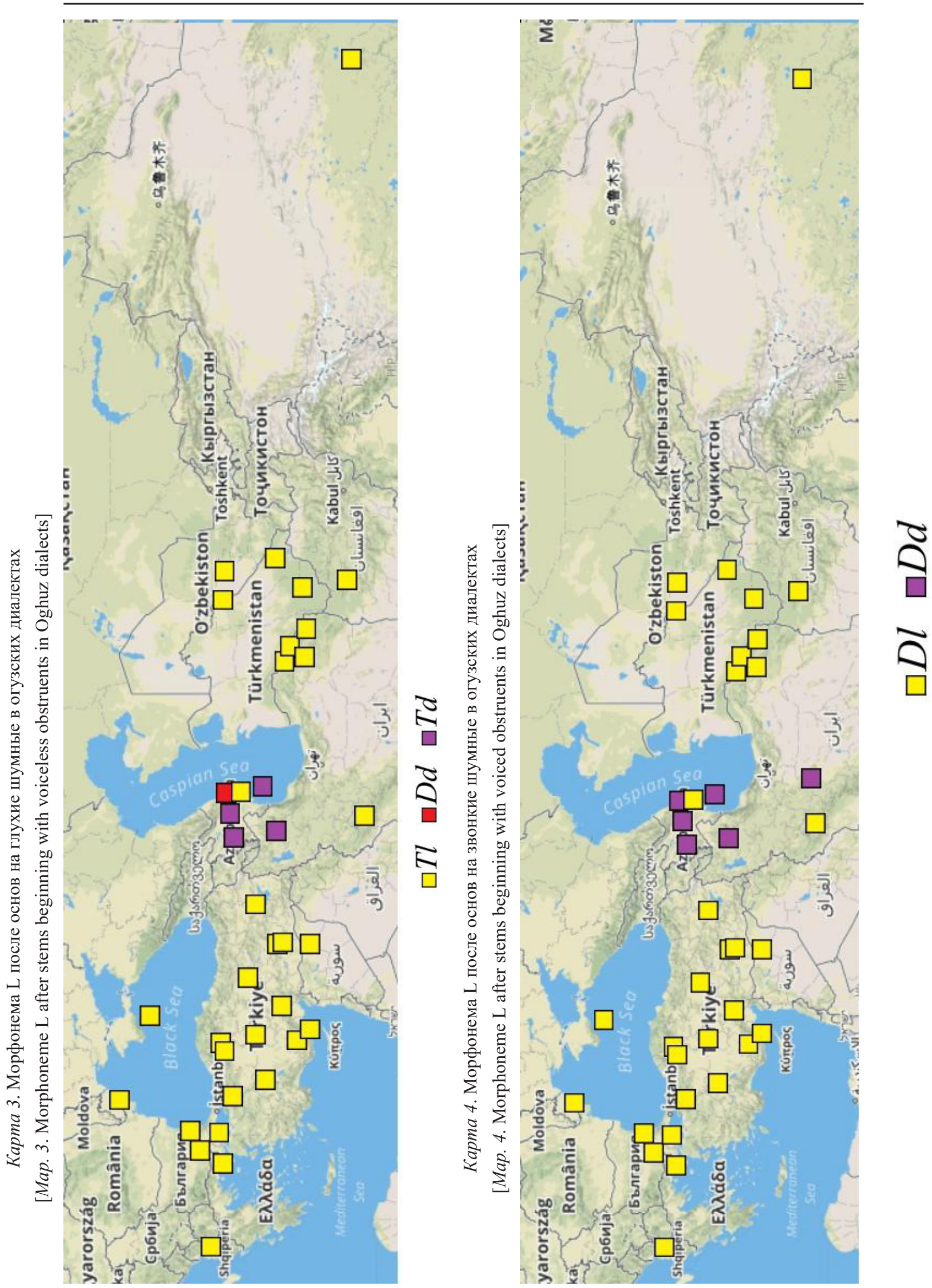
В. Обратимся к кыпчакским языкам. Как мы упоминали выше, достоверно кыпчакские памятники известны с XIII в. Ни для каких раннекыпчакских памятников не зафиксировано случаев никаких чередований начального L- в аффиксах под влиянием конечных согласных основ. В том числе это Codex Cumanicus, латинографический памятник кыпчакского куманского языка, начала XIV в.; по многим параметрам это западно-кыпчакский язык, вероятно, имеющий близкое отношение к караимским диалектам, а также, вероятно, к кумыкскому и карачаево-балкарскому (см., например: [Гаркавец 2019: 52-53]). Так же обстоят дела в армяно-кыпчакских половецких памятниках XVI в. (см.: [Грунин 1967: 358]).

Более восточные по происхождению кыпчакские тексты также не показывают никаких консонантных сандхи у рассматриваемых аффиксов (ср. XIII в.: [Houtsma 1894] barlï 'богатый', șaqalli 'бородатый', ațlu 'всадник', tatlu 'сладкий' saqla- 'остерегаться', mänli 'пятнистый', änlik 'румяна', anlar 'они', ornularïn 'их места' и т. д., не менее 50 случаев). Не наблюдается чередований и в памятнике XIV в. [Кононов, Фазылов, Зияева 1978: 433-438].

В языке письменных памятников Казанского ханства и позже в старотатарских и старобашкирских памятниках (до XVIII в. включительно) обнаруживаются только варианты -1Ar, -1A-, -1IK, -1I в том числе после носового конца основы, см.: [Хидиятов 2005: 25; Курбатов 2003; Хисамова 2015]3. Это касается как литературных произведений, так и деловых документов, переписки и даже воззваний из лагеря пугачевцев. При этом другие диалектные особенности, отличающие язык этих памятников от «хорезмийско-тюркского» или

${ }^{3}$ В книге [Нуриева 2004: 77, 136, 163, 253, 280] приведены формы из памятников XIVXV вв.: oylannar 'сыновья' (Кысас аль анбия, Нахджул ал-Фарадис), boүunnary 'суставы' (Нахджул ал-Фарадис), zӥnnar 'кресты' (Мухаббат-намэ, Гулистан), mujynnary 'их шеи' (Джумджума). Но их наличие не подтверждается другими изданиями памятников; примеры также отсутствуют в соответствующих разделах работы Ф. Ш. Нуриевой по этим памятникам в [Курбатов 2003] и [Хисамова 2015], и, таким образом, это опечатки под влиянием современного татарского. кодифицированного старотатарского литературного языка, появляются в тех же текстах по крайней мере с XVII в., например, позиционный и полный типы «джоканья» (выражается в употреблении буквы джим в начале исконно-тюркских слов на ПТ *j-) (см.: [Дыбо и др. 2020: 706-707]): ИдилЖайык 'Волга и Яик' (Джам-и ат-таварих, XVII в., в Касимове), жсил 'ветер’ (редко, в основном й-, Мауля Кулый, II пол. XVII в.), жсиз 'медный' (торговый акт XVIII в., [Курбатов 2003: 488, 498, 509]), ж⿻иулzучь дошманлар 'собравшиеся враги' (NB совр. дошманнар 'враги'), ж⿻иар 'соберут', жсиуб 'собрав', жсибәргәйсез 'отправьте', Жайық 'Яик', жситделәр 'прибыли', и др. (Пугачевские письма, II пол. XVIII в.), йөридер жсийалмай 'ходит, не может собраться' (Габдельмандан Муслимов, II пол. XVIII в.; возможно, позиционное «джоканье»), жсандырыр 'возродится' (Габдессалам, II пол. XVIII в., возможно, полное «Джоканье») [Хисамова 2015: 386-388]).

В течение всего XIX и начала XX в. в языке арабографичной татарско-башкирской литературы наблюдается различное отражение типов «жоканья - йоканья», и появляется различное отражение чередований $\mathrm{n} \sim 1$. Эти особенности, отчасти, видимо, обусловлены диалектной основой языка авторов, а отчасти употребление начального йай и отсутствие чередований может быть связано с ориентацией на староосманскую норму (что проявляется также в морфологических особенностях языка ряда авторов). Ср., например, полное йоканье в «Сәяхәтнамә» (издание основано на уфимской рукописи, см. [Курбатов 2003: 522-525]) при наличии чередования $\mathrm{n} \sim 1$ (угланнары 'тех парней' [Курбатов 2003: 536]; полное же йоканье при отсутствии чередований -L- у Курмаши (Притоболье, [Курбатов 2003: 565-575]); следы неполного жоканья татарского типа и отсутствие чередований -L- у Хибатуллы Салихова (жсир/йup, йул, яхшы, бунлар, Сакмарский район Оренбургской области) [Хисамова 2015: 409] и т. п.

Нормирование литературного татарского языка, составление нормативных грамматики и словарей прежде всего - заслуга Каюма Насыри (1825-1902, место рождения и ранних лет жизни - деревня Верхние Ширданы Свияжского уезда Казанской губернии; образование получено в Казанском 
медресе и университете). В его трудах мы обнаруживаем четкую систему «татарского неполного жоканья» (жсай 'лето', жсаулмак 'собираться', жсил 'ветер', жсир 'земля', йьlлан 'змея', йулдуз 'звезда', йаш 'молодой') и отсутствие чередований для L во всех соответствующих аффиксах (хайванлар 'скот', хатунль 'женатый') - см., хотя бы, [Насыри 1904]; в общем, это соответствует современным диалектологическим данным, см. ниже.

С другой стороны, со второй половины $\mathrm{XIX} \mathrm{в.} \mathrm{появляется} \mathrm{значительное} \mathrm{количество}$ текстов в кириллице, ориентированных на диалекты крещеных татар; социолингвистическую характеристику этих диалектов см., например, в [Berta 1988: 7].

Данные обследования миссионерских текстов, демонстрируемые в работах Ю. В. Норманской и ее соавторов, совпадают с полевыми данными 70-80-х гг. XIX в., собранными Г. Балинтом, в цитированной публикации А. Берта. Это диалекты со сплошным жоканьем и ассимиляцией начального 1-аффиксов предшествующим носовым конца основы. Те же особенности «народного татарского языка» находим в

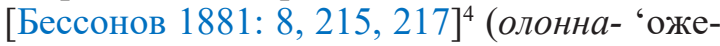
ребиться', бӓрӓннӓ- 'объягниться', кейемне 'имеющий одежду', кейемнӓ- 'доставить одежду’, жул жӧре- 'путешествовать'), [Катанов 1898: 20 (о сплошном џ- в начале слова), 29, 31, 39] (в транскрипциях: кийимнер 'одежды', уланнар 'сыновья', кӫннӓр 'дни', дөшманнары 'враги', ӱткіннігін 'остроты-Асc', урыннаш- 'селиться'. однако в арабографичной передаче этих же текстов всегда -nl-).

Любопытно, что, по-видимому, при создании татарской орфографической нормы в латинской графике было решено использовать компромиссный вариант между миссионерской кириллической «нормой» и арабографичной нормой по Каюму Насыри, cp. [Alparov 1934: 23]: «неполное жоканье» плюс anla- 'понимать', qomlb 'песчаный', qomlbq 'песчаное место', но qomnar 'пески', kөnnәr 'дни' и т. д. То есть наиболее частотный, словоизменительный аффикс множественного числа нормирован по «раз-

${ }^{4}$ Ср. там же примечание: «Замечательно также, что крещеные татары превращают в известных случаях звуки д и л флексий по ассимиляции в н, тогда как татары-мухамеддане почти никогда этого не делают». говорному» варианту, который в это время, судя по цитированным выше работам А. Г. Бессонова и Н. Ф. Катанова, социолингвистически преобладал, а прочие, словообразовательные аффиксы - по «книжному». От латинской орфографии эти нормы перешли в нынешнюю кириллическую.

Ситуацию в современных татарских диалектах обрисовывает карта № 55 в [АТНГ 2015]: для сибирско-татарских языков отмечены колебания -нл- - Hн- $^{5}$, в костромском, касимовском, бастиановском, азеевском и субдиалектах пензенского мишарского (с. Татаро-Никольское) сохраняется -нл-, регрессивная ассимиляция в =лл= отмечена на границе с Марий Эл (парангиньский диалект). Ср. в диалекте мордва-каратаев [Андреев 2007]: ӥлӓнлек 'лужайка', аңла'понимать', димлӓ- 'уговаривать', иркенлӓ- 'становиться просторным', иялтынлык 'стыдливость', туганлар 'родственники'.

Карта волгоуральских идиомов, построенная на наших экспедиционных материалах, в целом соответствует этой картине.

Конфигурация карты показывает, что показатель без алломорфии сохраняется в основном на дальней западной периферии ареала; алломорфы на -d действительно выстраиваются вдоль казахской границы, демонстрируя контактное происхождение, как и предполагается в [Норманская, Гаджиева 2020].

Очевидно, что для пра-волгоуральского состояния мы так же, как и для праогузского, не можем реконструировать алломорфов аффиксов на -L c -n после основ на носовой согласный, поскольку тогда сложно будет объяснить существование диалектов, где в этой позиции выступает -1 (и существование регрессивной ассимиляции в -11-); к тому же этому противоречит явно позднее появление алломорфов с -n в письменных памятниках.

В западнокыпчакских языках — караимском (всех трех диалектах), карачаево-балкарском, кумыкском и среднем крымско-татарском - чередования в этих аффиксах (как указано и в [Норманская, Гаджиева 2020]) отсутствуют.

В восточно-кыпчакских языках (или так называемой ногайской группе) распределе-

${ }^{5}$ Однако в текстах из сибирского диалектологического тома [ТХС 2008] никаких колебаний нет: все 1-аффиксы получают стабильно n после носового конца основы. 
Oriental Studies. 2020. Vol. 13. Iss. 5

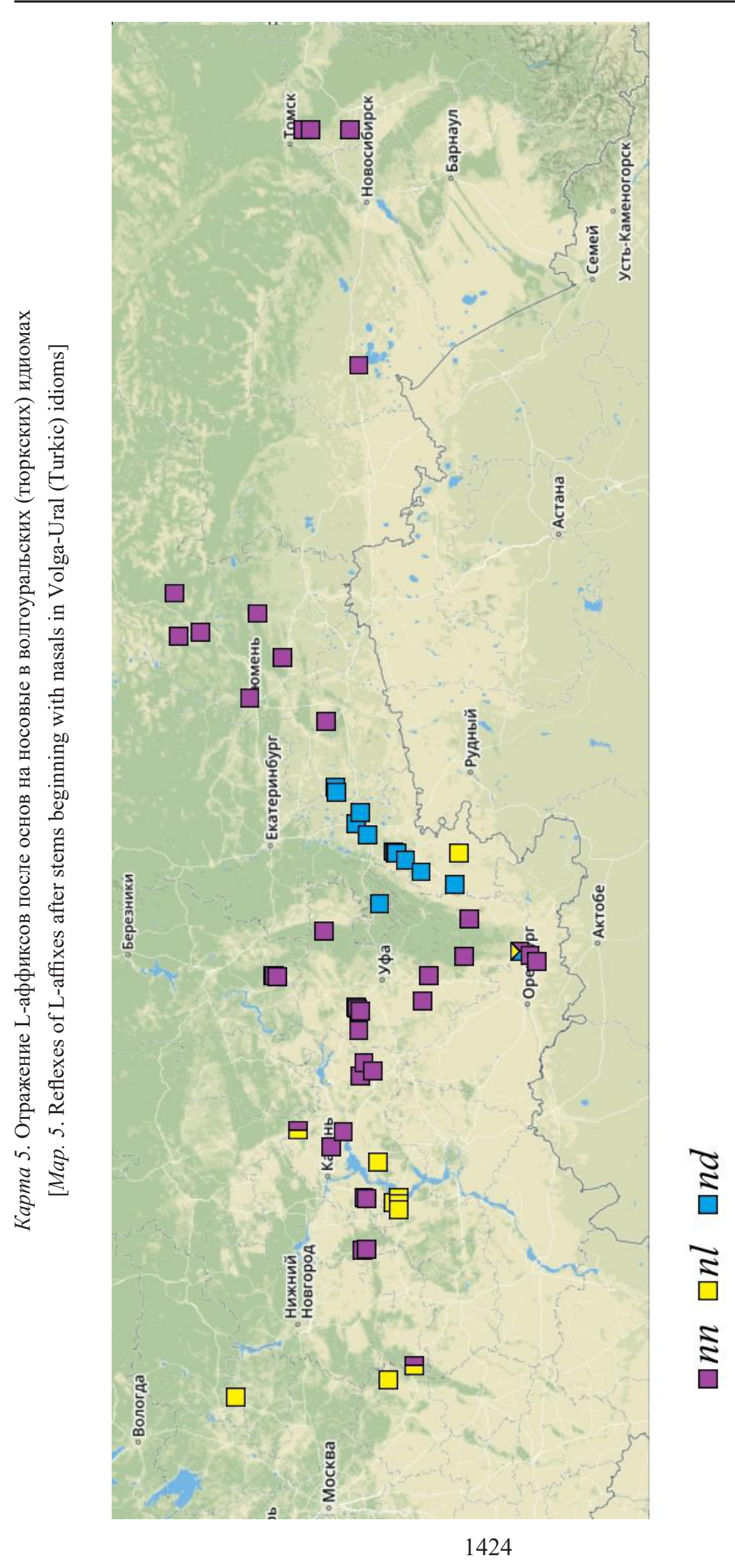




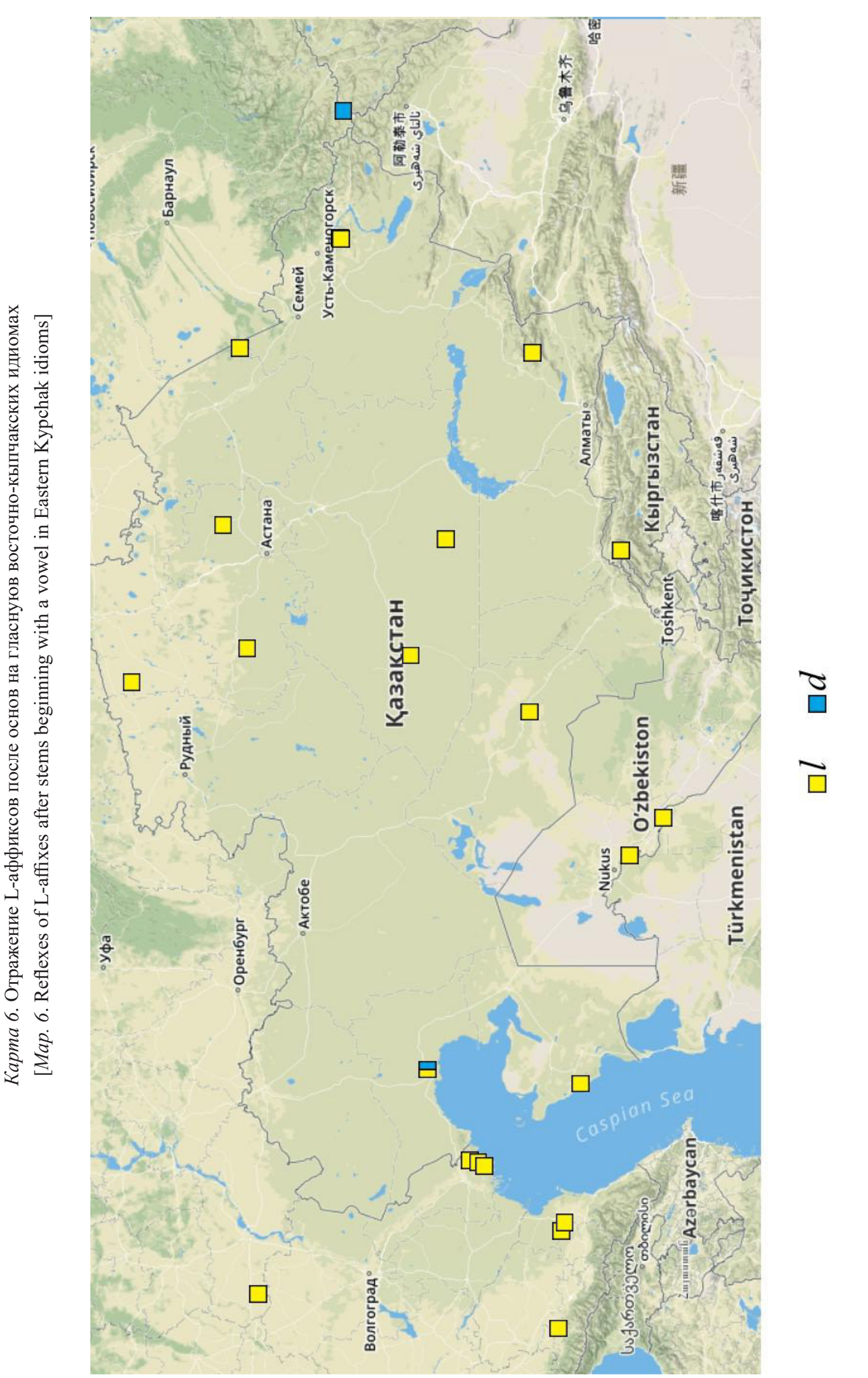


Oriental Studies. 2020. Vol. 13. Iss. 5

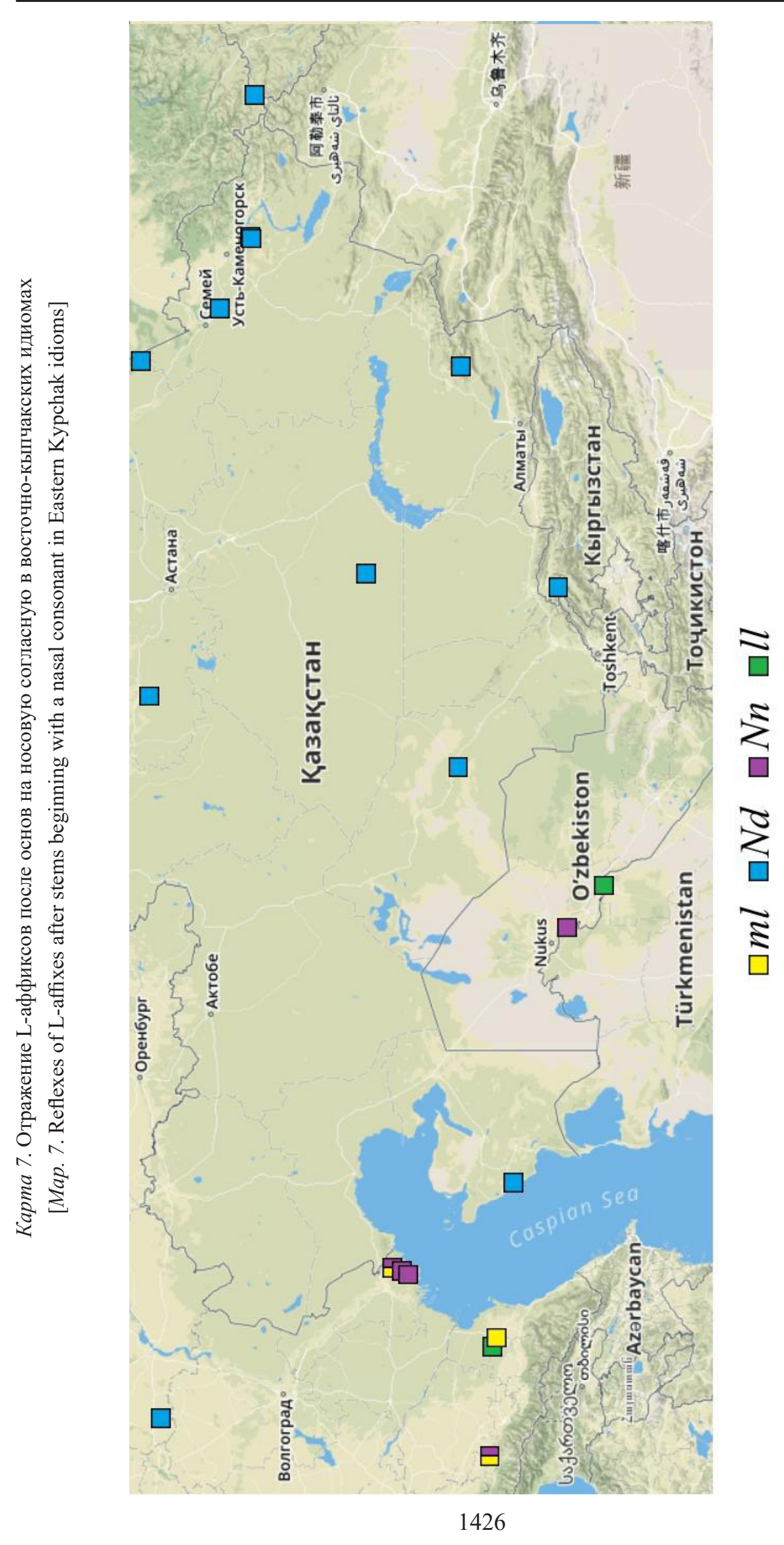




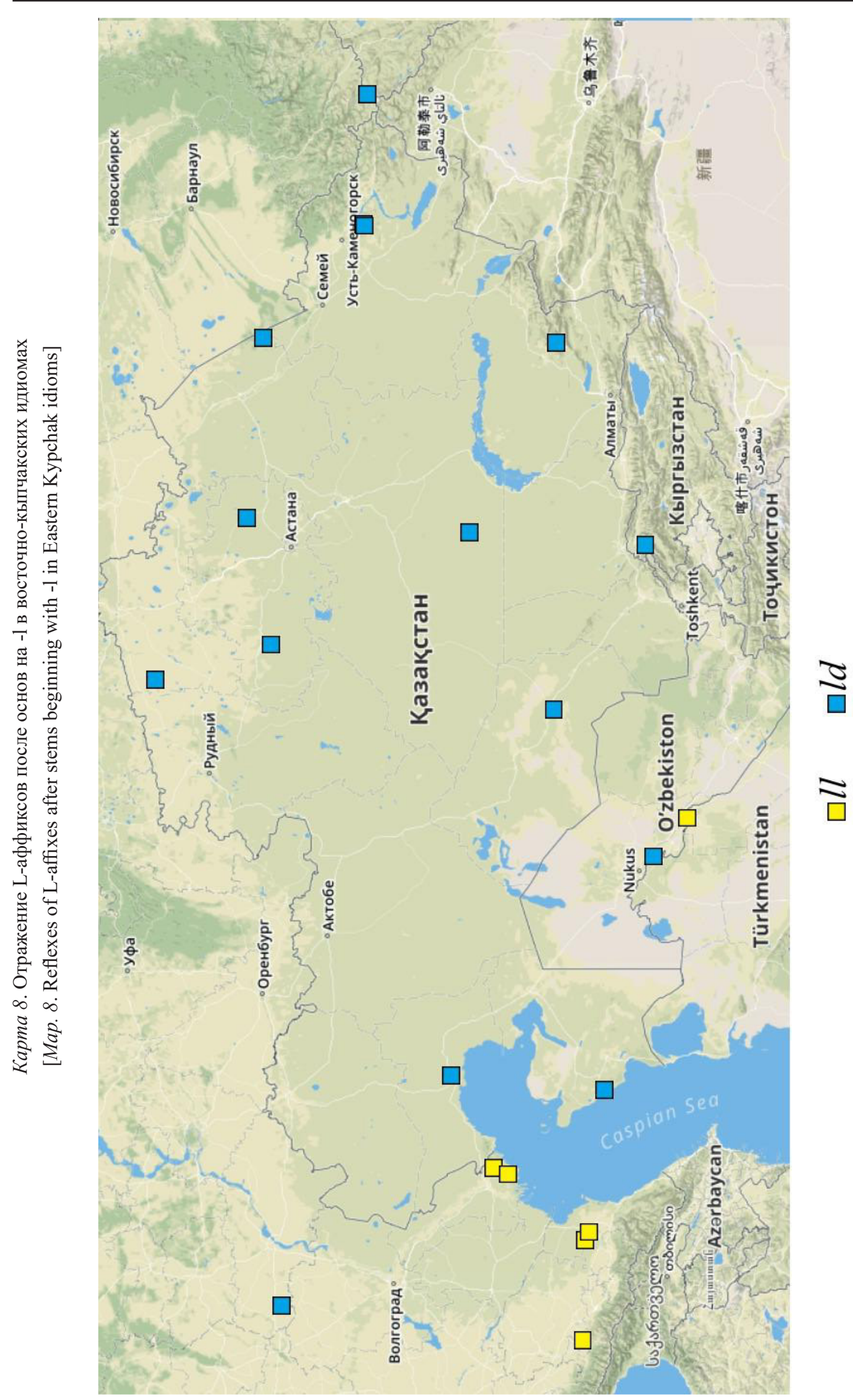


Oriental Studies. 2020. Vol. 13. Iss. 5

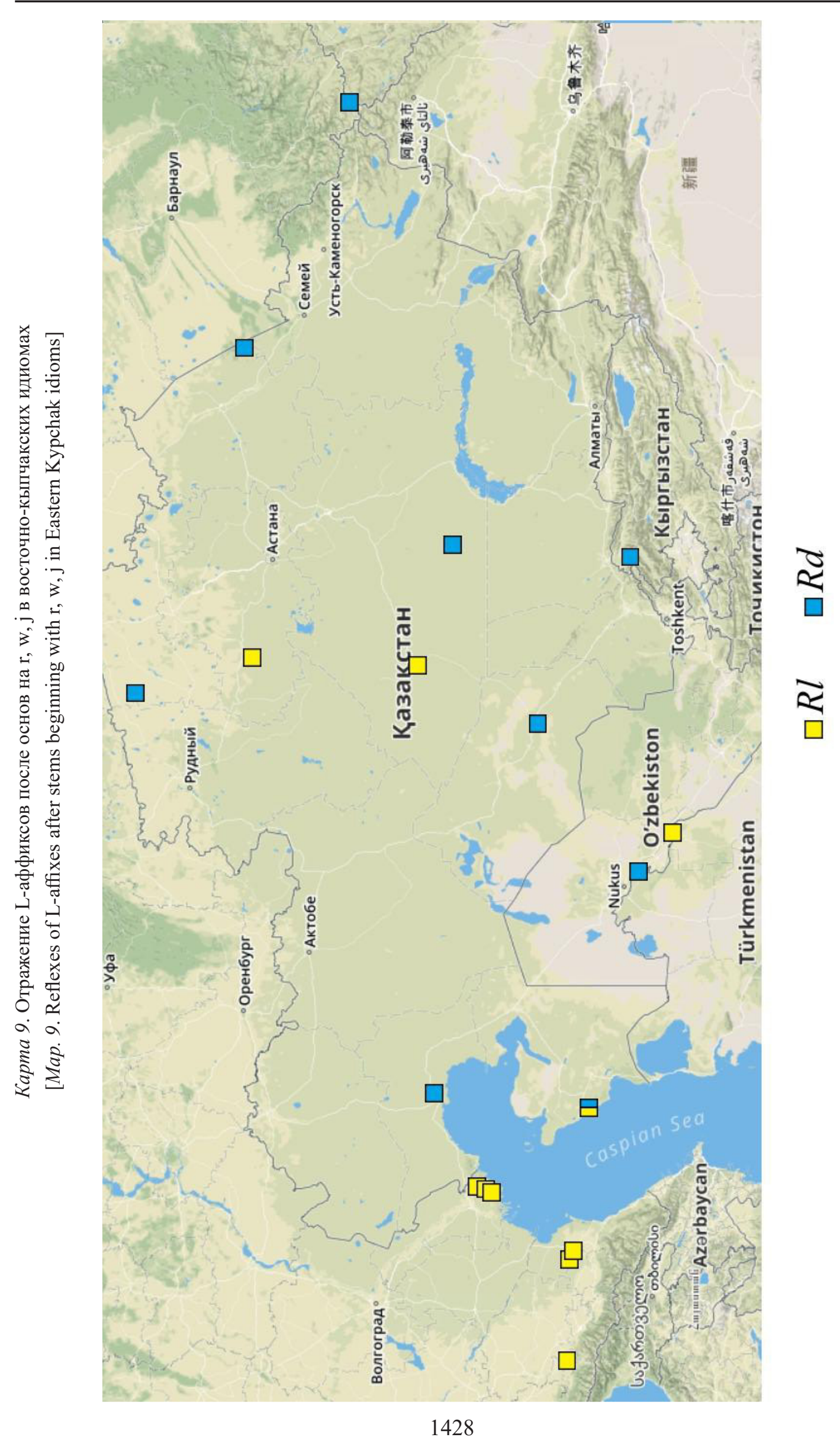




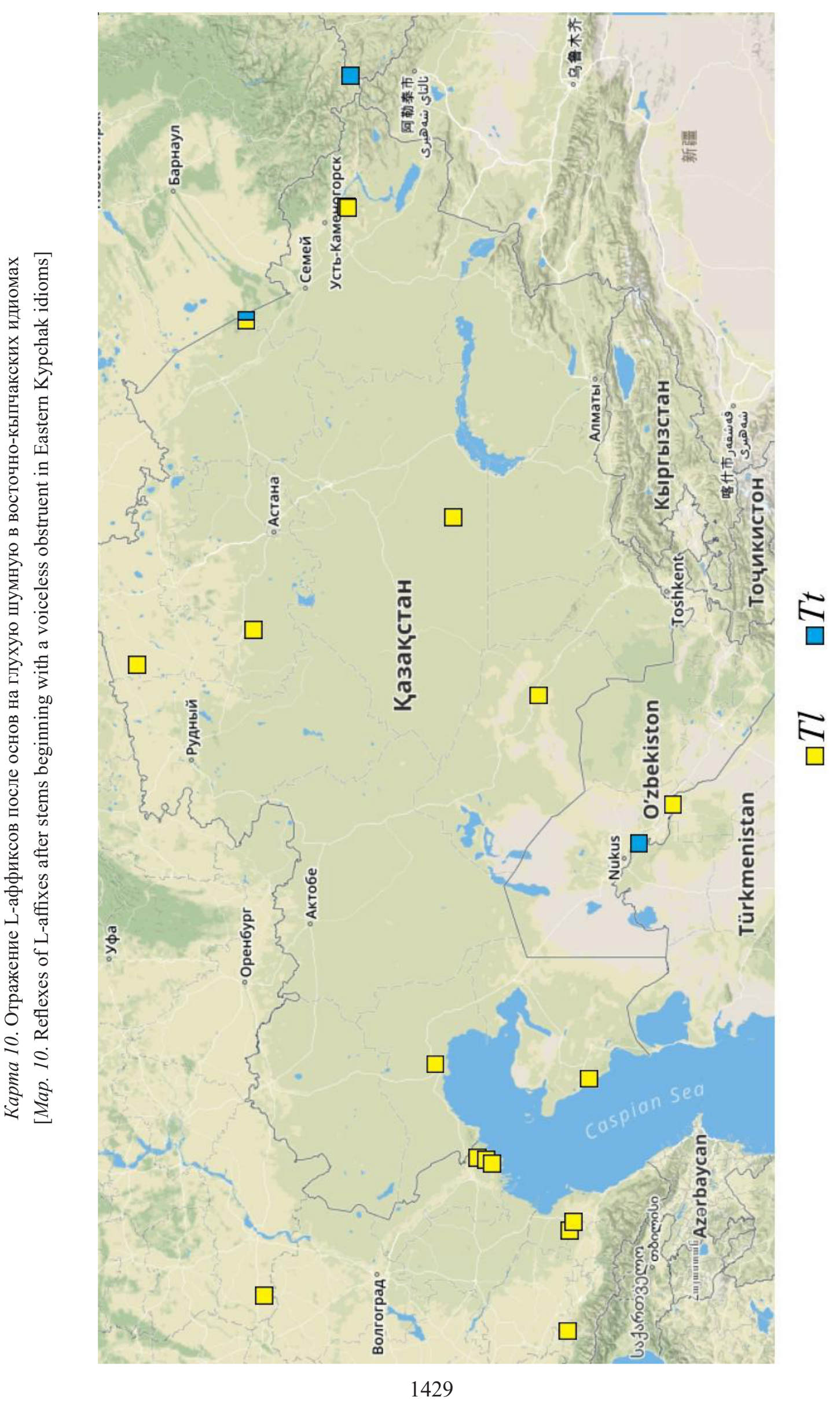




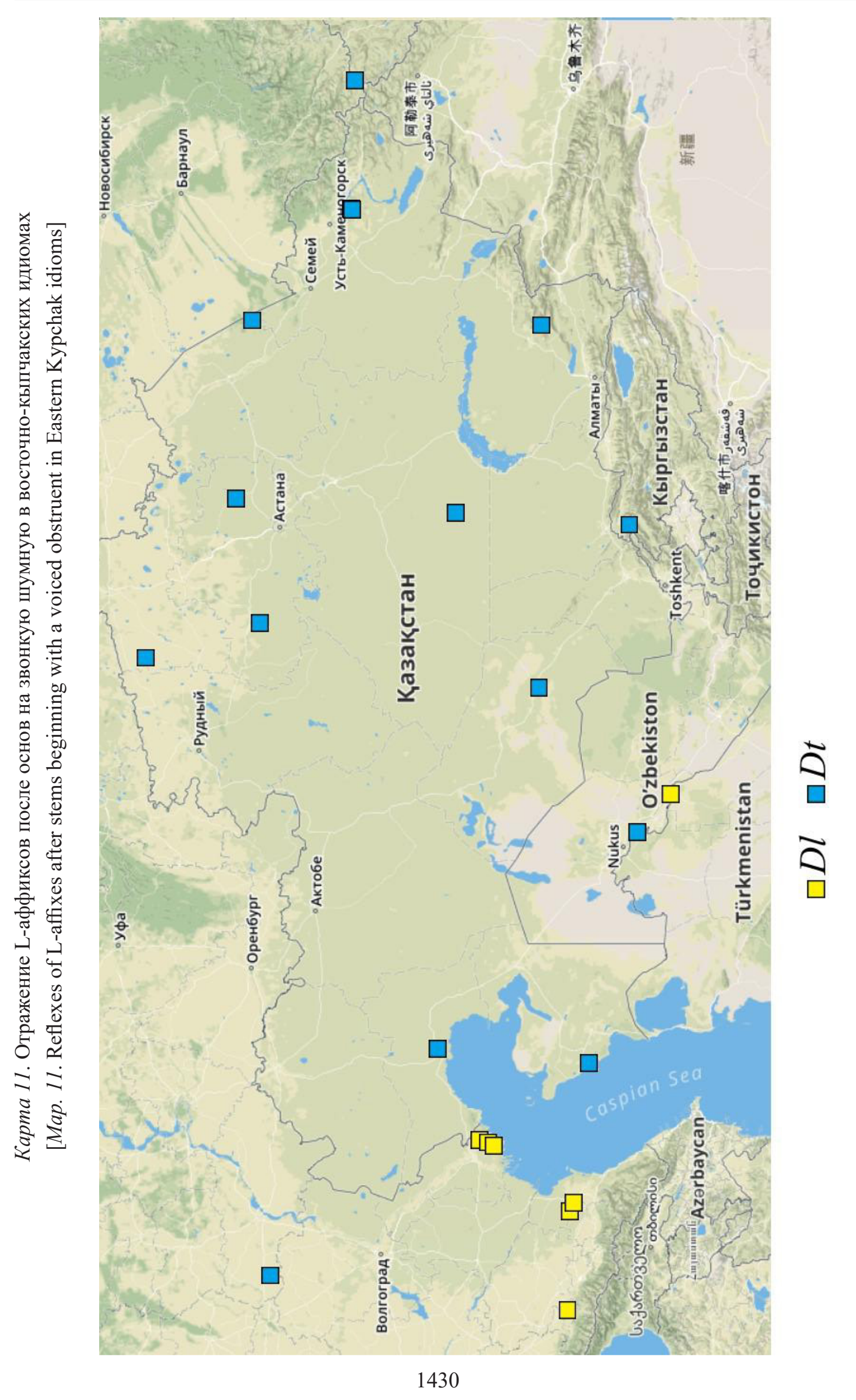


ние по современным экспедиционным материалам выглядит так.

В статье [Норманская, Гаджиева 2020] приводится форма из миссионерского памятника казахского языка 1891 г., [Премудрости 1891], по-видимому, отражающего западный диалект, Турганнарга 'стоящим', которая, как будто, указывает на отражение начального L в аффиксах как $\mathrm{n}$ после основ на носовую согласную в этом казахском диалекте. Верно отмечено, что в современных говорах западноказахского диалекта таких форм не наблюдается, и сделан вывод, что памятник отражает такой исторический срез, когда ранее существовавшие в этом диалекте формы на $\mathrm{Nn}$ заменялись на $\mathrm{Nd}$. При всей правдоподобности такого решения оно может быть оспорено. Дело в том, что для казахских диалектов XIX в. мы имеем еще несколько более раннюю кириллическую фиксацию, чем предоставляют нам описываемые миссионерские памятники. Это, прежде всего, работы Н. И. Ильминского по западному диалекту ([Ильминский 1860: 109]: «Это дало мне смелость издать „Материалы“, собранные мною частию в Оренбурге, частию в западной части зауральской степи, в кочевьях семиродцев и баюлинцев»). Для языка своих записей он выводит следующее правило [Ильминский 1860: 116]: аффиксы лАр, лА отыменного глагола, лЫ и лЫК производных имен, лАу неполноты проявления признака сохраняют л после гласных, дифтонгов (т. е. глайдов ј и w) и $\mathrm{p}$, и заменяют его на $\partial$ или $m$ после остальных согласных в зависимости от их звонкости/глухости (ср. ӧкпе́ле́ 'огорчаться', сырла- 'выкрасить', орла- 'окопать рвом', ӧрле́- 'дойти до вершины', урлук 'воровство', суула- 'измочить', сыіла- 'почитать', шанда- 'поднять пыль', арында- 'быть с норовом', шығында- 'идти неспокойно изза мух', е́мде- 'лечить', ӧсӥмдi 'возрастающий', ӧздерi 'они сами', септе- 'прибавить', ӧкӥтmе- 'советовать', ушты 'остроконечный').

То же правило, будучи, очевидно, фонетическим, действует на кластеры внутри основ, в частности, при адаптации заимствований: Алда 'Аллах', молда 'мулла', $а р$ стан 'лев'. Морфонологической аналогии подвергся коллективный аффикс *-da ̌̌, распределивший ступени чередования по тому же правилу: сырлас 'друг, которому поверяют тайны', суулас 'сидящий на одной реке' (с исключением kурдас 'ровесник')

Такие примеры мы встречаем и в приложенном словарике. Надо сказать, что описываемый Н. И. Ильминским идиом точно соответствует нашим представлениям о западном диалекте как в отношении этого типа рефлексов L, так и в отношении особенностей сингармонизма: узкий гласный в аффиксе после огубленного в основе не огубляется: cywль (но внутри основы губной сингармонизм на узком выдерживается: kойyн); широкий гласный после узкого огубленного огубляется ([Ильминский 1860: 115]: «е и е́ заменяются на ӧ после слога с ӱ: тӱсӧр вместо тӱсе́р ‘упадёт'»). Точно такое явление демонстрируют казахский словарь 1897 года и грамматика Катаринского 1906 года, отражающие западный диалект, о чем см.: [Дыбо, Норманская 2016: 147].

Словарик, приложенный в конце [Ильминский 1860], подтверждает эту систему многочисленными примерами (кӥјо 'моль', кёјӧк 'фартук для барана', кӥктӧ'шить на живую нитку', сијјӧм 'пядь', ӥјрӧк ‘утка’, $\ddot{д о р-~ ‘ к о ч е в а т ь ’ ~ и ~ т . ~ д .) . ~}$

Отметим, что описание Н. И. Ильминского не предполагает наличия алломорфа P1. -nAr, а также алломорфов -nA-, -nI, -nIK. Правило распределения ступеней чисто фонетическое (фонологическое), действует независимо от морфологической границы; мы также видим смену класса чередования у аффикса *-daš, получающего морфонологический облик -Las.

H. И. Ильминский там же отмечает сильное влияние татарского на письменную речь казахов. Так что, возможно, пример в [Премудрости 1891] (тем более, что больше таких примеров в отглоссированном тексте памятника не нашлось) обусловлен влиянием татарского языка на переводчика.

В. В. Радлов [Радлов 1870] в предисловии к своему изданию казахского фольклора характеризует материалы Н. И. Ильминского как относящиеся к западному диалекту, а свои - как восточные. Материалы В. В. Радлова также немного старше, чем использованный в статье [Норманская, Гаджиева 2020] миссионерский памятник

${ }^{6} \mathrm{Cp}$. аналогичное явление в группе туркменских диалектов: салыр., сарык. и зап. йомуд. -даш > лаш, см. [Амансарыев 1970: 220]. 
восточно-казахского диалекта [Крещение 1892], на основании одной формы из которого, ксидери 'люди его' (при наличии других форм от основ на гласную с -1-), Ю. В. Норманская и А. А. Гаджиева делают вывод о фиксации памятником временного среза, в котором в восточном диалекте казахского языка интервокальное -1 начала аффикса начинает замещаться на $-\mathrm{d}$.

В [Радлов 1870] действительно несколько раз встретились формы с -d после гласной: зордұк 'насилие' [Радлов 1870: 65, 66, 88], сонуударқа 'к последним' [Радлов 1870: 70], бурунбудар 'передние' [Радлов 1870: 185], баладары 'его дети' [Радлов 1870: 310], одардан 'от них', одарқа 'к ним' [Радлов 1870: 752]. Значительно больше в текстах форм с интервокальным 1. Надо сказать, примерно такое же количественное соотношение форм с d и с 1 в интервокале для аффиксов с начальным L демонстрируют и современные диалектные материалы с территории Казахстана; см., однако, подробно [Омарбеков 1992: 132-143], где алломорфы на -d считаются для восточных говоров (особенно для кош-агачского казахского) основным представителем L.

В труде [Березин 1890], цитируемом им, таких форм, действительно, значительно больше; в наших материалах по кошагачскому казахскому они практически регулярны. Похоже, таким образом, что речь тут должна идти не о разных временных срезах, отражающих разные этапы развития явления, а о материале разных говоров.

Разумеется, следует согласиться с тем, что такие формы для кыпчакских языков инновационны; однако очевидное доказательство этого - то, что для пракыпчакского они не могут быть реконструированы, поскольку в ряде кыпчакских языков чередование отсутствует, а вторичность 1 в каждой из позиций не поддавалась бы обоснованию.

Г. Пока у нас практически отсутствуют материалы по карлукским языкам; опираясь на [СИГТЯ 1988: 19-21; СИГТЯ 2002: $111-$ 113], можно утверждать, что в узбекских диалектах в основном неассимилируемое 1 (узб. тагаб. хотонлээ 'женщины', карш. одомла 'люди'; в ташк. обратная ассимиляция конца основы аффиксом: доллэ 'зёрна', ноллэ 'лепешки': так же в илийском уйгурском по материалам Ю. В. Норманской в
Lingvodoc': jaqilar 'воротники', илаллар 'змеи', долкунлар 'волны', учкунлар 'искры', йоллар 'пути', кушлар 'птицы', отлар 'огни', йултузлар 'звезды').

В некоторых узбекских карлукских говорах выступает $n$ после носовой основы (по перечислению в [СИГТЯ 2002] это Андижан, Коканд, Уйчи, Ошоб, Ю. Киргизия, также Кашкай и Джума). Таким образом, мы и здесь имеем дело с независимыми поздними ассимиляциями, не возводимыми к праязыковому состоянию.

Сибирская ситуация в основном точно представлена в таблице в статье [Норманская, Гаджиева 2020]. Следует только заметить две вещи, имеющие отношение к окончательным выводам.

Во-первых, данные по тубаларскому, извлеченные из замечания [ГАЯ 1869: 10], вероятно, неточны. Там приводится форма улуглар 'большие' как существующая «у кондомцев и черневых» (и «черневые» можно понять как «тубалары», но это не обязательно так: «таежными» и «горными», что, собственно, синоним «черневых», называют себя также шорцы и часть хакасов). Но форма улуглар для тубаларского невозможна, поскольку *-g на конце слова в тубаларском превращается в глайд w, который после широких гласных сохраняется, а после узких пропадает, оставляя огубленный вокалический конец: улу 'большой, старший'; may 'гора'. В таком виде эти формы представлены уже в [Радлов 1866: 241, 244, 246, 247, 248, 250-262]. В том же томе Радлова форма улуглар встречается на с. 409, и это сойонский, т. е. тувинский, текст. Возможно, что в ГАЯ в данном случае имелась в виду кондомская шорская форма улуглар.

Во-вторых, то, что все рассмотренные правила являются инновационными, доказывается не только и не столько с помощью карты, но и с помощью установления порядка действия правил, приводящих к существующим распределениям в языковых группах и языках.

Так, можно наблюдать, что вариант -tAr после глухих шумных захватывает связный ареал от якутского (в таких формах, как мас-тар 'дерево-P1', где он обусловлен чи-

7 Lingvodoc [электронный ресурс] // URL: http://lingvodoc.ispras.ru/dictionary/79/4/ perspective/79/6/view (дата обращения: 25.08.2020). . 
сто морфонологически, а не дублированием аффикса -t), тувинского и тофаларского, «кыргызских» языков, челканского, кумандинского, тубаларского, алтайского, теленгитского, телеутского через киргизский, казахский восточный, северный (отчасти и западный) и башкирский восточный (и некоторые говоры ик-сакмарского южного), не касаясь сибирско-татарского и каракалпакского, где варианты -лАр и -нАр. Этот связный ареал, несомненно, довольно новый, не имеющий отношения к генеалогической классификации языков и диалектов, так как распространившаяся изоглосса захватила оглушенный на востоке старый звонкий *-z конца основы (совпавший в этом регионе $\mathrm{c}^{*}$-s). При этом в тувино-тофаларской группе совпадение ${ }^{*}-\mathrm{z}$ c *-s явно произошло после выделения этой группы, потому что тувино-тофаларская фарингализация отсутствует в словах со старым *-z независимо от долготы предшествующего гласного и присутствует в словах на *-s с первично кратким гласным. В западной же своей части изоглосса основ на -*z не захватывает, поскольку там он остается фонологически

\section{Литература}

Амансарыев 1970 - Амансарыев Ж. Түркмен диалектологиясы. Ашгабат: Түркменистан, 1970. 382 c.

7 По степени единообразия во входящих в кладу идиомах можно вывести алломорфию аффиксов на *-1 на прауровень «кыргызской», т. е. хакасско-шорско-чулымской группы (см.: [Норманская, Гаджиева 2020: табл. 3]). Любопытно, что, по-видимому, для всей группы выводятся на прауровень две морфонемы типа 1: как обозначили мы их в модели хакасской словоформы, трехвариантная Л (л/н/т) и двухвариантная L (л/н) (см.: [Дыбо и др. 2019]). Первая работает во всех рассматривавшихся здесь словоизменительных и словообразовательных аффиксах; вторая содержится в аффиксе континуатива (встраиваемой частицы) и в аффиксе глаголообразования от звукоподражаний (в отличие от стандартного аффикса глаголоообразования от имен ЛА), ср.: майтлат- 'шлепать по воде' $\{$ майт=LA=(Ы)T- $\}$ 'звукоподражание шлепанию=Oper=Caus'; мыхлас- 'пищать вместе' $\{$ мых $=\mathrm{LA}=(\mathrm{Ы}) \mathrm{C}-\} \quad$ 'звукоподражание писку=Oper=Rec-'. В шорском языке мы также, кроме обычного трехвариантного Л в рас- звонким. Та же изоглосса захватывает оглушенный *-d в якутской и тувинской группах (як., тув. боттар 'сами') и оглушенный *-s $<*$-d в кыргызской группе (хак. постар (сами'). То есть, очевидно, что распространение правила прошло через границы генеалогических групп и после прохождения конституирующих эти группы процессов ${ }^{7}$.

\section{Выводы}

Итак, на рассмотренном материале можно достаточно убедительно показать, что морфонологические изоглоссы, касающиеся алломорфии стандартно-тюркского аффикса множественного числа *-1Ar, это конгломерат инновационных процессов, довольно случайным образом захватывающих разные части «тюркского мира» и распространяющихся в ряде случаев согласно «волновой модели», не будучи связанными c генеалогическим членением тюркских языков. Но для доказательства этого оказалось необходимо применять ступенчатую реконструкцию, то есть отдельно рассматривать поведение аффиксов в каждой из генеалогических группировок.

Андреев 2007 - Андреев В. П. Словарь языка каратаев. Казань: Слово, 2007. 187 с.

АТНГ 2015 - Атлас татарских народных говоров. Изд. 2-е. Казань: ИЯЛИ, 2015. 632 с.

смотренных аффиксах, находим формы типа тарыслак 'треск', нырлапчыткан 'шумяще' (о волнах) (т. е. образования от звукоподражаний сохраняют л после шумных глухих) и «усилительную или подтвердительную» частицу ла/на (вариант с $н$ после носовых) [Дыренкова 1941: 245]. (В существующих описаниях среднечулымского пока подробные разделы о встраиваемых частицах и звукоподражаниях отсутствуют, так что о наличии в нем морфонемы L нам неизвестно). При этом формальные соображения заставляют нас счесть двухвариантность морфонемы более поздним явлением, чем трехвариантность: двухвариантное чередование работает (в случае с частицей) в сандхи, которое еще недавно было внешним (первое из мест континуативной частицы в словоформе - после старой формы деепричастия основного глагола перед вспомогательным), или до сих пор является почти внешним - на конце словоформы. Видимо, здесь мы имеем дело с новой волной ассимилятивных процессов. 
Березин 1890 - Турецкая хрестоматия, составленная профессором С.-Петербургского университета И. Березиным. Т. 3. Казань: Тип. Казанского университета, 1890. 385 с.

Бессонов 1881 - Бессонов А. Г. О говорах казанского татарского наречия и об отношении его к ближайшим к нему наречиям и языкам // Журнал Министерства народного просвещения. Ч. CCXVI. СПб., 1881. С. 200-242.

Гаркавец 2019 - Гаркавеи A. H. Codex Cumanicus. Второе полное издание, дополненное. Алматы: Алматы-Болашак, 2019. $1360 \mathrm{c}$.

ГАЯ 1869 - Грамматика алтайского языка, составлена членами алтайской миссіи. Казань: Университетская типография, 1869. 298 с.

Грамматика 1981 - Грамматика современного башкирского литературного языка / 3. 3. Абсалямов, М. Х. Ахтямов, Т. М. Гарипов и др.; отв. ред. А. А. Юлдашев. М.: Наука, 1981. 495 с.

Грунин 1967 - Грунин Т. И. Документы на половецком языке XVI в: судебные акты каменец-подольской армянской общины. М., Наука, 1967. 429 с.

Дыбо 2012 - Дьбо А. В. Морфонологический анализ и внутренняя реконструкция: к истории башкирского языка // Актуальные проблемы диалектологии языков народов России: мат-лы XII рег. конф. (г. Уфа, 2728 ноября 2012 г.) / редкол.: Л. А. Бускунбаева и др.; сост. Р. Н. Каримова. Уфа: ИИЯЛ, Уфимский НЦ РАН, 2012. С. 65-69.

Дыбо 2017 - Дыбо А. В. Еще раз об истории показателей лично-числового спряжения в тюркских языках // Урало-алтайские исследования. 2017. № 3 (26). С. 127-150.

Дыбо и др. 2019 - Дьго А. В., Крылов Ф. С., Мальиева В. С., Шеймович А. В. Сегментные правила в автоматическом парсере Корпуса хакасского языка // Урало-алтайские исследования. 2019. № 1(32). С. 48-69.

Дыбо и др. 2020 - Дыбо А. В., Абубакирова Л. Ф., Айбазова 3. К., Зимин М. М., Коровина Е. В., Мальцева В.С., МудракО.А., РенковскаяЕ.А., Савельев А. В., Хисамов О. Р., Шаров А. В., Шеймович $A$. B. Новые результаты в генеалогической классификации тюркских диалектов («случаи с аффрикатами») // Oriental Studies. 2020. T. 13. № 3. C. 696-713.

Дыбо, Норманская 2016 - Дыбо A. В., Норманская Ю. В. Первые кириллические книги на казахском языке как источник для изучения диалектов и создания литературной нормы // Урало-алтайские исследования. 2016. № 4 (23). С. 138-152.

Дыренкова 1941 - Дыренкова Н. П. Грамматика шорского языка / отв. ред. С. Е. Малов. М.; Л.: Изд-во АН СССР, 1941. 308 с.

Ильминский 1860 - Ильминский H. И. Материалы к изучению киргизского наречия. Книга IV // Ученые записки, издаваемые Императорским Казанским университетом. Казань: Тип. ун-та, 1860. С. 107-162.

Катанов 1898 - Катанов Н. Ф. Материалы к изучению казанско-татарского наречия. Часть первая. Образцы книжной и устной литературы казанских татар. Казань: типо-литогр. Имп. ун-та, 1898. 168 с.

Кононов, Фазылов, Зияева 1978 - Кононов А. Н., Фазылов Э. И., Зияева М. Т. Изысканный дар тюркскому языку: грамматический трактат XIV в. на арабском языке. Ташкент: Фан, 1978. $452 \mathrm{c}$.

Крещение 1892 - Ауліе княз Владимир тура динге бзи де крип; орыс калкын-да кргизгени. Крещение Руси на киргизскомъ языке. Казань: тип. наследников М. А. Чирковой, $1892.27 \mathrm{c}$.

Курбатов 2003 - История татарского литературного языка (XIII - первая четверть XX в.) / ред. Х. Курбатов. Казань: Фикер, 2003. $656 \mathrm{c}$.

Насыри 1904 - Абдулъ-Каюмъ бинъ Абду-ННасыри-и-ль-Казани. Полный русско-татарский словарь, съ дополнением изъ иностранныхъ словъ, употребляемыхъ въ русскомъ языкъ какъ научные термена. Казань: Тип. Казанского университета, 1904. 264 с.

Норманская, Гаджиева 2020 - Норманская Ю. В., Гаджиева A. А. Как изменилась форма показателя множественного числа в тюркских языках за последние 150 лет // Oriental Studies. 2020. T. 13. № 4. C. 11211134.

Нуриева 2004 - Нуриева Ф. Ш. Исторические и лингвистические условия формирования тюрко-татарского литературного языка золотоордынского периода. Казань: Каз. гос. ун-т, 2004. 384 с.

Омарбеков 1992 - Омарбеқ̧ов С. География фонетических различий казахской речи (Сравнительный аспект системы согласных). Алма-Ата: Рауан. 1992. 224 с.

Премудрости 1891 - Акыл бере тугун кнеге (Изъ премудрости Іисуса сына Сирахова). 
Казань: Типография и литография В. М. Ключникова, 1891. 55 с.

Радлов 1866 - Радлов В. В. Образцы народной литературы тюркских племен, живущих в южной Сибири и Дзунгарской степи. Ч. 1. Поднаречия Алтая: алтайцев, телеутов, черновых и лебединских татар, шорцев и саянцев. СПб.: Тип. Имп. акад. наук, 1866. $453 \mathrm{c.}$

Радлов 1870 - Радлов В. В. Образцы народной литературы тюркских племен, живущих в южной Сибири и Дзунгарской степи. Ч. 3. Киргизское наречие. СПб.: Тип. Имп. акад. наук, 1870.814 с.

СИГТЯ 1988 - Сравнительно-историческая грамматика тюркских языков: Морфология / отв. ред. Э. Р. Тенишев. М.: Наука, 1988. $560 \mathrm{c.}$

СИГТЯ 2002 - Сравнительно-историческая грамматика тюркских языков: Региональные реконструкции / отв. ред. Э. Р. Тенишев. М.: Наука, 2002. 767 с.

TXC 2008 - Татар халык сөйләшләре: Ике китапта / Ф. С. Баязитова, Д. Б. Рамазанова, T. Х. Хәйретдинова h. б. (= Татарские народные говоры: в двух книгах). Казань: Мәгариф, 2008. Беренче китап. 463 б.; Икенче китап. 495 б.

Хидиятов 2005 - Хидиятов И. Р. Язык письменных памятников периода Казанского ханства (XVI в.) и татарские говоры в сравнительном аспекте: морфология: дис. ... канд. филол. наук. Казань, 2005. 247 с.

Хисамова 2015 - Хисамова Ф. М. (фәнни

\section{References}

Adamović M. Konjugationsgeschichte der türkischen Sprache (Turkish Language: History of Conjugation). Leiden: Brill, 1985, 357 p. (In Germ.)

Alparov G. Tatar Literary Language: Spelling Rules. Kazan: Tatgosizdat, 1934. 40 p. (In Tat)

Amansaryev J. Turkmen Dialectology. Ashgabat: Türkmenistan, 1970. 382 p. (In Turk.)

Andreev V. P. A Dictionary of the Language Spoken by the Karatays. Kazan: Slovo, 2007. 187 p. (In Tat.)

Bayazitova F. S., Ramazanova D. B., Khayretdinova T. Kh. Tatar Folk Dialects. In 2 vols. Kazan: Mägarif, 2008. Vol. 1, 463 p.; vol. 2, 495 p. (In Tat.)

Berezin I. A Turkish Chrestomathy Compiled by Prof. I. Berezin (Imperial St. Petersburg ред.) Татар әдәби теле тарихы (XIII гасыр - XX йөз башы) (= История татарского литературного языка (с XIII по начало XX в.) / И. Б. Бәширова, Ф. Ш. Нуриева, Э. Х. Кадыйрова. I т.: Фонетика. Графика: язма традицияләр, норма һәм вариантлылык. Казан: ТӘһСИ, 2015. 696 б.

Adamović 1985 - Adamović M. Konjugationsgeschichte der türkischen Sprache. Leiden: Brill, 1985. $357 \mathrm{~S}$.

Alparov 1934 - Alparov G. Tatar ədəbi telenen, orfografiə qaoidələrə. Qazan: Tatgosizdat, 1934. $40 \mathrm{c}$.

Berta 1988 - Wolgatatarische Dialektstudien. Textkritische Neuausgabe der Originalsammlung von G. Bálint 1875-76. Hrsg. von Á. Berta. Budapest: Magyar tudományos akadémia könyvtára, 1988. $413 \mathrm{~s}$.

Clauson 1972 - Clauson G. An Etymological Dictionary of Pre-Thirteenth-Century Turkish. Oxford: Clarendon Press. 1972. 988 p.

Erdal 1991 - Erdal M. Old Turkic Word Formation. V. 1-2. Wiesbaden: Otto Harassowitz. 1991. $874 \mathrm{p}$.

Erdal 2004 - Erdal M. A grammar of Old Turkic. Leiden: Brill, 2004. 576 p.

Grønbech 1942 - Grønbech K. Komanisches Wörterbuch: türkischer Wortindex zu Codex Cumanicus. Kopenhagen: Einar Munksgaard, 1942. $315 \mathrm{~S}$

Houtsma 1894 — Ein Türkisch-Arabisches Glossar, nach der Leidener Handschrift. Hrsg. und erläutert von M. Th. Houtsma. Leiden: Brill. 1894. $192 \mathrm{~S}$.

University). Kazan: Imperial Kazan University, 1890. Vol. 3. 385 p. (In Turk. and Russ.)

Berta Á. (ed.) Wolgatatarische Dialektstudien. Textkritische Neuausgabe der Originalsammlung von G. Bálint 1875-76 (Dialectology of the Volga Tatars. New Critical Edition of G. Bálint's 1875-76 Original Collection). Budapest: Hungarian Academy of Sciences (Library), 1988. 413 p. (In Germ.)

Bessonov A. G. Revisiting subdialects of Kazan Tatar, and the latter's relation to its closest dialects and languages. Zhurnal Ministerstva narodnogo prosveshcheniya. 1881. No. CCXVI. Pp. 200-242. (In Russ.)

Christianization of (Kievan) Rus' by Vladimir the Great: In the Kirghiz Language. Kazan: Heirs of M. A. Chirkova, 1892. 27 p. (In Kaz.) 
Clauson G. An Etymological Dictionary of PreThirteenth-Century Turkish. Oxford: Clarendon Press, 1972, 988 p. (In Eng.)

Dybo A. V. Again on the subject of the history of personal-numeral conjugation in Turkic languages. Ural-Altaic Studies. 2017. No. 3 (26). Pp. 127-150. (In Russ.)

Dybo A. V. Morphonological analysis and internal reconstruction: history of the Bashkir language revisited. In: Karimova R. N. (comp.), Buskunbaeva L. A. et al. (eds.) Languages of Russia's Peoples. Topical Issues of Dialectology. Conference Proceedings (Ufa; November 2728, 2012). Ufa: Institute of History, Language and Literature (Ufa Scientific Center of RAS), 2012. Pp. 65-69. (In Russ.)

Dybo A. V., Krylov F. S., Maltseva V. S., Sheymovich A. V. Segmental rules in the automatic parser for the Khakass corpus. UralAltaic Studies. 2019. No. 1 (32). Pp. 48-69. (In Russ.)

Dybo A. V., Normanskaja J. V. The first Cyrillic books in Kazakh as a base for studying the history of dialects and creating a literary standard. Ural-Altaic Studies. 2016. No. 4 (23). Pp. 138152. (In Russ.)

Dybo A. V., Abubakirova L. F., Aibazova Z. K., Hisamov O. R., Korovina E. V., Maltseva V. S., Mudrak O. A., Renkovskaya E. A., Savelyev A. V., Sharov A. V., Sheimovich A. V., Zimin M. M. Some new results in the genealogical classification of Turkic dialects: 'cases of affricates'. Oriental Studies. 2020. Vol. 13. No. 3. Pp. 696-713. (In Russ.)

Dyrenkova N. P. Grammar of the Shor Language. S. Malov (ed.). Moscow; Leningrad: USSR Academy of Sciences, 1941. 308 p. (In Russ.)

Erdal M. A Grammar of Old Turkic. Leiden: Brill, 2004. 576 p. (In Eng.)

Erdal M. Old Turkic Word Formation. Vols. 1-2. Wiesbaden: Otto Harassowitz, 1991. 874 p. (In Eng.)

Garkavets A. N. Codex Cumanicus: Second Complete Edition, Suppl. Almaty: AlmatyBolashak, 2019. 1360 p. (In Russ.)

Grammar of the Altaian Language Compiled by Members of the Altaian Orthodox Mission. Kazan: Imperial Kazan University, 1869. 298 p. (In Russ.)

Grønbech K. Komanisches Wörterbuch: türkischer Wortindex zu Codex Cumanicus (Dictionary of Cuman: Index of Turkish Words to Codex Cumanicus). Copenhagen: Einar Munksgaard,
1942. 315 p. (In Germ. and Turk.)

Grunin T. I. $16^{\text {th }}$-Century Polovtsian (Cuman)Language Documents: Judicial Acts of Kamianets-Podilskyi Armenian Community. Moscow: Nauka, 1967. 429 p. (In Russ.)

Houtsma M. Th. (ed.) Ein Türkisch-Arabisches Glossar, nach der Leidener Handschrift (A Turkish-Arabic Glossary, Compiled on the Basis of the Leiden Manuscript). Leiden: Brill, 1894. 192 p. (In Turk., Arab. and Germ.)

Ilminsky N. I. Kirghiz Dialect: Research Materials. Uchenye Zapiski, izdavaemye imperatorskim Kazanskim universitetom. 1860. No. 4. Pp. 107162. Available at: http://kazneb.kz/bookView/ view/?brId=1550712 (accessed: July 20, 2020). (In Kaz. and Russ.)

Katanov N. F. Kazan Tatar Dialect: Research Materials. Part One: Samples of Printed and Oral Literature of Kazan Tatars. Kazan: Imperial Kazan University, 1898. 168 p. (In Tat. and Russ.)

Khidiyatov I. R. $16^{\text {th }}$-Century Tatar Language of Written Monuments (Khanate of Kazan) and Tatar Dialects: A Comparative Morphological Perspective. Cand.Sc. (philology) thesis. Kazan, 2005. 247 p. (In Russ.)

Khisamova F. M. (ed.) History of the Tatar Literary Language: $13^{\text {th }}$ to the Early $20^{\text {th }}$ Century. I. Bashirova, F. Nurieva, E. Kadyirova. Kazan: Institute of Language, Literature and Art (Tatarstan Academy of Sciences), 2015.Vol. I: Phonetics. Graphics. 696 p. (In Tat.)

Kononov A. N., Fazylov E. I., Ziyaeva M. T. A Sophisticated Gift to the Turkic Language: $14^{\text {th }}$-Century Arabic-Language Grammar. Tashkent: Fan, 1978. 452 p. (In Russ.)

Kurbatov Kh. R. (ed.) History of the Tatar Literary Language: $13^{\text {th }}-$ First Quarter of $20^{\text {th }}$ Century. Kazan: Fiker, 2003. 656 p. (In Russ.)

Nasiri Q. A Complete Russian-Tatar Dictionary, Supplemented with Foreign Words Used in the Russian Language as Scientific Terms. Kazan: Imperial Kazan University, 1904. 264 p. (In Russ. and Tat.)

Normanskaya Yu. V., Gadzhieva A. A. Turkic plural forms: changes over the last 150 years revisited. Oriental Studies. 2020. Vol. 13. No. 4. Pp. 1121-1134. (In Russ.)

Nurieva F. Sh. The Shaping of the Golden Horde Literary Turkic Tatar: Historical and Linguistic Conditions. Kazan: Kazan State University, 2004. 384 p. (In Russ.)

Omarbeқоv S. Geography of Phonetic Differences in Spoken Kazakh: The Consonant System in 
a Comparative Perspective. Alma-Ata: Rauan, 1992. 224 p. (In Russ.)

Radlov V. V. Turkic Tribes of Southern Siberia and Dzungar Steppe: Samples of Folk Literature. Part 1: Subdialects of the Altai, including Those of Altaians, Teleuts, Tubalars, Chelkans, Shors and Soyots. St. Petersburg: Imperial Academy of Sciences, 1866. 453 p. (In Russ., Alt., etc.)

Radlov V. V. Turkic Tribes of Southern Siberia and Dzungar Steppe: Samples of Folk Literature. Part 3: Kirghiz Dialect. St. Petersburg: Imperial Academy of Sciences, 1870. 814 p. (In Russ. and Kaz.)

Ramazanova D. B., Khayrutdinova T. Kh. (eds.) Atlas of Tatar Folk Dialects. $2^{\text {nd }}$ ed. Kazan:
Institute of Language, Literature and History, 2015. 632 p. (In Tat. and Russ.)

Tenishev E. R. (ed.) Comparative Historical Grammar of the Turkic Languages: Morphology. Moscow: Nauka, 1988. 560 p. (In Russ.)

Tenishev E. R. (ed.) Comparative Historical Grammar of the Turkic Languages: Regional Reconstructions. Moscow: Nauka, 2002. 767 p. (In Russ.)

The Book of Sirach. Excerpts. Kazan: V. Klyuchnikov, 1891. 55 p. (In Kaz.)

Yuldashev A. A. (ed.) Grammar of the Modern Bashkir Literary Language. Z. Absalyamov, M. Akhtyamov, T. Garipov et al. Moscow: Nauka, 1981. 495 p. (In Russ.) 